\title{
Supplementation of Holstein dairy calves fed two levels of crude protein with methionine and lysine
}

\author{
M. Niroumand, K. Rezayazdi \& M. Ganjkhanlou \\ Department of Animal Science, Agricultural and Natural Resources College, University of Tehran, Daneshkadeh \\ Ave., 77871-31587, Karaj, Alborz, Iran
}

(Received 3 June 2019; Accepted 18 June 2020; First published online 13 July 2020)

\begin{abstract}
Copyright resides with the authors in terms of the Creative Commons Attribution 4.0 South African Licence.
See: http://creativecommons.org/licenses/by/4.0/za

Condition of use: The user may copy, distribute, transmit and adapt the work, but must recognise the authors and the South African Journal of Animal Science.
\end{abstract}

\begin{abstract}
This study aimed to investigate various levels of crude protein (CP) in starter diets and their supplementation with amino acids (AAs) on efficiency, health, and serum metabolites of dairy calves. Ninetysix newborn Holstein calves were allocated to eight treatments, namely T1) $18 \%$ CP unsupplemented starter, T2) T1 supplemented with additional $20 \%$ methionine, T3) T1 with additional $20 \%$ lysine and $20 \%$ methionine, T4) T1 with additional 20\% lysine, T5) 22\% CP unsupplemented starter, T6) T5 supplemented with additional $20 \%$ methionine, T7) T5 supplemented with additional $20 \%$ lysine and $20 \%$ methionine, and T8) T5 supplemented with additional $20 \%$ lysine. Consumption of the starter was not influenced by the level of CP. Calves that received the unsupplemented $22 \%$ CP starter had higher average daily gain (ADG) and final weight. But no significant differences among diets were found in feed efficiency. Skeletal growth did not exhibit a clear trend. Calves that received T3 had fewer bouts of diarrhea and reduced body temperature. However, there were no significant dietary effects on immunoglobin $\mathrm{G}(\mathrm{lg} G)$ or total protein concentration in blood. T1-T3 decreased serum urea concentration. Thus, use of T3 resulted in an improved amino acid balance, and was less expensive than the $22 \% \mathrm{CP}$ starter.
\end{abstract}

Keywords: amino acid, feed intake, immunity, pre-ruminant calf

\# Corresponding author: rezayazdi@ut.ac.ir

\section{Introduction}

Reducing the feed costs of the dairy calves is one of the critical issues with which dairy farmers are faced (Babu et al., 2003). Usually protein accounts for the highest amount of the ration cost, although it is regarded as an important part in balancing diets for livestock. The amount of protein is important in the diet of pre-ruminant calves, because the consequences of levels of concentration of protein that are too low or too high (Li et al., 2008) are reduced animal production, welfare and a polluted environment. Numerous researches (Blome et al., 2003; Lohakare et al., 2006) have studied the precise definition of the need for protein by pre-ruminant dairy calves and the best level of protein in milk replacer. The National Research Council (NRC, 2001) provides the most acceptable criteria for feeding dairy cattle (Bartlett et al., 2006). However, there are not enough studies on the most suitable amount of CP in the solid feed of pre-ruminant calves. In addition, although the NRC (2001) has recommended requirements of non-synthesizable AAs for various animal species, including beef cattle, dairy cows, chickens, sheep, and swine, their diets remain suboptimal regarding growth, development, reproduction, lactation and health (Guoyao et al., 2014). The NRC model indicates that $18 \%$ crude protein (CP) on a DM basis in the starter should be adequate for calves that are fed with enhanced milk replacer, and that energy supply, rather than CP supply, would be a limiting factor for growth. However, data to determine the need for increased CP or metabolizable protein concentration in the starter are inconclusive (Stamey et al., 2012). In addition, few studies have been conducted to establish the AA requirements of calves (Hill et al., 2008) that are younger than one or two months. Methionine and lysine are generally the first limiting AA when milk protein is replaced with protein from soybeans (Wang et al., 2012).

Blome et al. (2003) and Bartlett et al. (2006) reported enhanced ADG from increasing amounts of CP and of various ratios of CP to energy in feeding of calves fed only with milk. More recently, Hill et al. (2006b; 2007c) showed that a starter with $26 \% \mathrm{CP}$ and $17 \%$ fat milk replacer supported higher ADG than one that 
contained $20 \% \mathrm{CP}$ and $20 \%$ fat. Feeding a $20 \%$ CP milk replacer at $0.45 \mathrm{~kg} / \mathrm{d}$ that was supplemented with lysine and methionine improved ADG. A 17\% improvement in ADG resulted from the addition of lysine and methionine to a maximum of $2.34 \%$ lysine. The linear and quadratic ADG responses to added methionine were equal to $13 \%$ and $7 \%$, respectively, with a plateau at $0.72 \%$ methionine. There was no response in ADG and efficiency to added threonine (Hill et al., 2007b). Similarly, supplementing lysine, methionine, threonine, and isoleucine increased ADG in pre-ruminant calves that received milk replacer with proteins of milk and soy (Jenkins \& Emmons, 1983; Kanjanapruthipong, 1998).

Stamey et al. (2012) studied the growth performance of Holstein dairy calves that received various amounts of CP in their solid feed. Moderate advantages were observed in their solid feed intake and growth performance, especially around weaning, with a starter with $25.5 \%$ CP (DM basis) compared with a lower amount of CP (19.6\%).

Studies that evaluated the effects of reducing the CP level in the starter and adding AAs on the performance of dairy calves were not available in the articles that the authors reviewed. Thus, the present study aimed to assess the effect of CP level in the starter with the addition of various levels of lysine and methionine on the growth performance, feed efficiency and wellbeing of pre-ruminant calves and some blood metabolites. The research hypothesis was that reducing the CP level in calf starter and adding some essential AAs would improve the performance of dairy calves.

\section{Materials and Methods}

The study was carried out at the facilities of a local dairy farm that had been approved by the Animal Care and Use Committee of the Iranian Council of Animal Care (1995). The protocol of the present study was similarly evaluated and approved.

In total, 96 three-day-old Holstein calves $(38.56 \pm 1.75 \mathrm{~kg}$ of bodyweight (BW) (mean $\pm \mathrm{SD}$ ) were weighed and moved to individual pens $(1.2 \times 2.5 \mathrm{~m})$ with sand beds, which were replaced every 24 to 48 hours as needed. They had been fed with four litres of colostrum within six hours of birth, and colostrum feeding continued for the first three days of their lives. Blood samples were taken from the jugular vein by venipuncture at 24 hours after the first colostrum intake and were sent to a laboratory for analysis. Serum total protein was determined as an indicator of passive transfer of immunity. Only neonatal calves with a serum level of protein greater than $6 \mathrm{~g} / \mathrm{dL}$ were kept in the study. Calves were bucket-fed twice a day with pasteurized whole milk (at $08 \mathrm{~h} 00$ and $18 \mathrm{~h} 00,50 \%$ each time) according to an adjusted step up/step down milk feeding protocol with $5 \mathrm{~L} / \mathrm{d}$ milk from days 1 to $14,6 \mathrm{~L} / \mathrm{d}$ milk from days 15 to $28,5 \mathrm{~L} / \mathrm{d}$ milk from days 29 to 42 , and $3 \mathrm{~L} / \mathrm{d}$ milk from days 43 to 56 of the study. All calves were weaned at day 56 of the experiment.

Twelve calves (six male and six female) were allocated to each of eight treatments in a $2 \times 2 \times 2$ factorial arrangement based on a completely randomized design. The factors were CP level of starter ( $18 \%$ and 22\%), methionine level in starter (basal level and basal plus 20\%) and lysine level in starter (basal level and basal plus 20\%). All diets were isocaloric and differed only in the CP content and the amounts of lysine and methionine.

Before the experiment began, basal diets ( $\mathrm{T} 1$ and $\mathrm{T} 5$ ) were made up in the feed plant of the dairy farm, then a sample was taken from each diet and sent to the specialized laboratory to determine the current level of methionine and lysine in the diet using Pico-Tag, HPLC method (White et al., 1986). Additional methionine and lysine were included in the diets according to the laboratory results. The components of the experimental diets and their nutrients are shown in Table1.

Equal amounts of milk were fed to all calves. Starter intake was measured every morning. Calves were weighed on days 1,7 , then weekly using an electronic balance. Average daily weight gain and feed efficiency ratio ( $\mathrm{kg}$ of BW gain/ $\mathrm{kg}$ of total dry matter intake) were computed for pre-weaning, post weaning, and the overall period. Blood samples were obtained from the jugular vein by venipuncture at days 30 and 70 of the study into a vacuum tube containing clot activator three hours after morning feeding, and placed on ice immediately. Tubes were centrifuged at $3000 \times \mathrm{g}$ for 15 minutes to separate the serum, then kept at -20 ${ }^{\circ} \mathrm{C}$ for further analysis.

Serum creatinine and urea were specified by colorimetric and enzymatic assays (Pars Azmoon Co., Tehran, Iran). Serum immunoglobulin was determined according to the immunoturbidimetric method using a commercial kit (Pars Azmoon Co., Tehran, Iran). Total protein was measured photometrically based on the Biuret method with a commercial kit (Pars Azmoon Co, Tehran, Iran). Feed samples were taken weekly from all diets, and were oven-dried at $70^{\circ} \mathrm{C}$ and kept for subsequent analysis for $\mathrm{CP}$.

Skeletal growth of the calves, including the length of body, body girth, height of withers, height of hip and the width of hip, was recorded at the start, at weaning (day 56) and at the end of the study (day 70) according to Khan et al. (2007). Two bulk milk samples from two consecutive days were collected at twoweekly intervals and were kept at $4{ }^{\circ} \mathrm{C}$ in tubes containing potassium dichromate as preservative until analysis by Milkoscan (Daneshvar et al., 2017). Total solid concentration of milk samples was used to 
calculate total DMI (dry matter intake). Spot faecal samples were taken directly from the rectum on the last three days of the experiment. Manure samples were collected from all calves four hours after feeding. The samples were frozen immediately at $-15^{\circ} \mathrm{C}$ for subsequent analysis.

Table 1 Ingredients, energy and nutrient composition of experimental diets fed to dairy calves for 70 days on dry matter basis

\begin{tabular}{|c|c|c|c|c|c|c|c|c|}
\hline \multirow{2}{*}{ Ingredients } & \multicolumn{8}{|c|}{ Experimental diets } \\
\hline & $\mathrm{T} 1$ & T2 & T3 & $\mathrm{T} 4$ & T5 & T6 & T7 & T8 \\
\hline Corn grain, \% & 63.15 & 63.134 & 62.794 & 62.810 & 51.30 & 51.273 & 50.877 & 50.904 \\
\hline Soybean meal, \% & 23.90 & 23.90 & 23.90 & 23.90 & 35.95 & 35.95 & 35.95 & 35.95 \\
\hline Soybean seed, \% & 5 & 5 & 5 & 5 & 5 & 5 & 5 & 5 \\
\hline Fat supplement ${ }^{1}, \%$ & 2.95 & 2.95 & 2.95 & 2.95 & 2.75 & 2.75 & 2.75 & 2.75 \\
\hline Di-calcium phosphate, \% & 2 & 2 & 2 & 2 & 2 & 2 & 2 & 2 \\
\hline Salt, \% & 0.50 & 0.50 & 0.50 & 0.50 & 0.50 & 0.50 & 0.50 & 0.50 \\
\hline Sodium bicarbonate, $\%$ & 1 & 1 & 1 & 1 & 1 & 1 & 1 & 1 \\
\hline Mineral supplement ${ }^{2}, \%$ & 0.75 & 0.75 & 0.75 & 0.75 & 0.75 & 0.75 & 0.75 & 0.75 \\
\hline Vitamin supplement ${ }^{3}, \%$ & 0.75 & 0.75 & 0.75 & 0.75 & 0.75 & 0.75 & 0.75 & 0.75 \\
\hline Added methionine ${ }^{4}, \%$ & & 0.016 & 0.016 & & & 0.027 & 0.027 & \\
\hline $\begin{array}{l}\text { Added lysine }{ }^{5}, \% \\
\text { Chemical composition }\end{array}$ & & & 0.340 & 0.340 & & & 0.396 & 0.396 \\
\hline Crude protein, \% (lab result 6 ) & 18.35 & 18.35 & 18.35 & 18.35 & 21.85 & 21.85 & 21.85 & 21.85 \\
\hline Crude protein, \% (calculated) & 18.46 & 18.47 & 18.43 & 18.42 & 22.63 & 22.66 & 22.61 & 22.59 \\
\hline Methionine, $\mathrm{g} / \mathrm{kg}$ & 2.56 & 2.64 & 2.64 & 2.56 & 2.61 & 2.76 & 2.75 & 2.61 \\
\hline Lysine, g/kg & 9.14 & 9.14 & 9.14 & 9.14 & 9.69 & 9.69 & 9.69 & 9.69 \\
\hline Rumen degradable protein, $\%$ & 61.36 & 61.33 & 61.35 & 63.85 & 63.92 & 63.87 & 63.9 & 63.94 \\
\hline Rumen undegradable protein, \% & 38.64 & 38.67 & 38.65 & 36.15 & 36.08 & 36.13 & 36.1 & 36.06 \\
\hline Microbial protein, $\mathrm{g}$ & 121.86 & 121.86 & 121.93 & 121.93 & 121.19 & 121.19 & 121.27 & 121.26 \\
\hline Total absorbable protein, $\mathrm{g}$ & 161.99 & 162.10 & 162.01 & 161.91 & 170.82 & 170.99 & 170.9 & 170.72 \\
\hline ME, Mcal/kg & 3.18 & 3.18 & 3.18 & 3.18 & 3.19 & 3.19 & 3.19 & 3.19 \\
\hline NEG, Mcal/kg & 1.49 & 1.49 & 1.49 & 1.49 & 1.49 & 1.49 & 1.49 & 1.49 \\
\hline NEM, Mcal/kg & 1.96 & 1.96 & 1.96 & 1.96 & 1.96 & 1.96 & 1.96 & 1.96 \\
\hline
\end{tabular}

T1: 18\% CP unsupplemented starter, T2: T1 supplemented with 20\% methionine, T3: T1 supplemented with $20 \%$ lysine and 20\% methionine, T4: T1 supplemented with 20\% more lysine, T5: 22\% CP unsupplemented starter, T6: T5 supplemented with $20 \%$ more methionine, T7: T5 supplemented with $20 \%$ more lysine and $20 \%$ more methionine, and T8: T5 supplemented with 20\% more lysine; ME: metabolizable energy, NEG: net energy for growth, NEM: net energy for maintenance

${ }^{1}$ Contained (\% DM) stearic acid: 5\%, palmitic acid: 30\%, oleic acid: $11 \%$, linoleic acid: $50 \%$, and linolenic acid: $4 \%$

${ }^{2}$ Contained (mg/kg) Co: 100, Cu: 4,290, I: 200, Mn: 10,000, Zn: 20,000, Mg: 67,500, and Ca: 240,000

${ }^{3}$ Contained (IU/kg) vitamin A: $1,300,000$, vitamin D: 360,000 , and vitamin E: 12,000

${ }^{4}$ Rumen protected methionine with $74 \%$ purity

${ }^{5}$ Rumen protected lysine with $50 \%$ purity

${ }^{6}$ Standard error of repeated lab assays 0.84 and 0.79 for T1-T4 and T5-T8, respectively

The factorial treatment arrangement consisted of two dietary CP levels, two methionine levels, and two lysine levels. Bodyweight, starter consumption, ADG, and gain-to-feed ratio (G: F) were analysed using the MIXED procedure in SAS software (version 9.4, SAS Institute Inc., Cary, NC) specifying repeated measures for pre-weaning (from days 1 to 56 of the study), post weaning (from days 57 to 70), and overall (from days 1 to 70). Significance was declared at $P<0.05$ and trends were considered when $0.05<P<0.10$. Differences among means were assessed using the LSD procedure. 


\section{Results and Discussion}

The three-factor interaction of $\mathrm{CP}$, lysine, and methionine levels was significant for starter intake during both the pre-weaning and post-weaning periods and overall for ADG during the preweaning period and overall, weaning weight and final weight, and the intake of $\mathrm{CP}$, lysine, and methionine. Those calves that were fed T7 had the lowest starter intake, whereas calves fed T5 had the highest intake. Calves fed $20 \%$ more lysine generally had higher starter intakes, and calves fed $20 \%$ more methionine had lower starter intake than the basal amount. Feeding T5 resulted in the greatest total ADG, and calves fed with T7 had the least ADG pre-weaning and during the experiment. In general, T4 and T8 increased ADG, while T2 and T6 reduced it. Despite the significant effects on starter intake and ADG, no effects of treatment on gain-to-feed ratio were detected throughout the experiment. Starter intake, ADG, and feed efficiency data are reported in Table 2.

The initial measurement at day 3 was regarded as a covariate factor. Although there were differences between treatments, values of body length, body girth, height of withers, height of hip and width of hip did not reveal conclusive differences between groups, so the least body growth was observed in T6 (except for wither height at weaning), but which experimental diet led to the greatest growth could not be concluded. The results of skeletal growth at weaning and at the end of the experiment are shown in Table 3.

The T3 starter led to the highest hip height, while calves fed T5 had the highest wither height. However, feeding T8 led to the highest body girth and body length. Calves fed T6 were widest at the hips.

In this study, although there were significant differences in starter intake and ADG level between treatments during the experiment, pre- and post-weaning, the CP level of starter did not have a significant effect on these parameters, possibly because 18\% CP had greater digestibility, which provided more nitrogen in the small intestine for digestion and absorption (Manso et al., 1994). This is contrary to the results of Stamey et al. (2012), who reported that starter intake with $25.5 \%$ CP was greater than starter intake with $19.6 \%$ CP.

Variations in calf starter intake have been shown to account for over half of the variations in total BW gain in the same period (Kertz et al., 1979). The degree to which calf growth rates slump around weaning may reflect information on development of the rumen and microbial digestion at the time of weaning (Stamey et al., 2012). In this study, all calves were weaned at 56 days old, regardless of the amount of solid feed intake. The low ADG post weaning (weeks 9 and 10) in calves that consumed low or high CP starter may be owing to lower rumen development and consequently lower starter intake. Lack of significant differences in skeletal growth may be due to the same effect. Starter nutrients would be subjected to some degradation in the immature rumen, and should have lower post-ruminal digestibility than milk protein (Hill, 2008).

The level of CP did not have a significant effect on dry matter intake, ADG and feed efficiency during the whole period may be because the source of protein was the same in all diets, so the change in CP level did not lead to change in palatability of the starter. Although total absorbable protein was higher in diets with $22 \%$ CP (Table 1), the ineffectiveness of this CP level is probably owing to the higher levels of rumen undegradable protein and microbial protein in diets with $18 \% \mathrm{CP}$, which had been absorbed with higher efficiency in the small intestine, and compensated for less total absorbable protein. The effect of lysine level on overall $A D G$ was numerically higher and was effective on overall ADG and final weight, but did not influence overall feed efficiency. Calves that received $20 \%$ more lysine had higher final weight. However, methionine had a significant effect on feed intake, overall ADG and feed efficiency. Higher methionine led to a decrease in feed intake and consequently lower ADG, weaning and final weight, and higher feed efficiency, which is probably because of amino acid imbalance. When consumed with lysine, it led to a higher feed intake and ADG $(P<0.01)$. Despite differences in ADG and feed intake between treatments, feed efficiency was not significantly different over the experiment. Probably the higher starter intake was not proportional to weight gain.

Crude protein had an effect only on wither height (calves that received 22\% CP had higher wither height), and did not influence other skeletal growth parameters. However, the higher level of lysine led to the higher barrel girth, hip width and height at weaning and at the end of the experiment. On the other hand, the higher level of methionine led to lower hip height, body girth, body length at weaning and less hip height, wither height, body girth and body length at the end of the experiment, probably owing to the amino acid imbalance. In the study by Stamey et al. (2012), they found that the starter (conventional CP level or enriched) did not influence skeletal growth parameters, which agrees with the present study. But the study by Tahmasebi et al. (2014) showed that the protein source of the starter had an effect on body girth. Body girth is correlated with DMI, thus calves with higher DMI had higher body girth. In the present study, calves with less DMI also had lower body girth.

There were differences in bouts of diarrhoea and rectum temperature between treatments $(P<0.05)$. Calves fed T3 had fewer bouts of diarrhoea and lower rectal temperature $(P<0.05)$. Calves that received T7 
had more bouts of diarrhoea, and calves received T3 had higher rectal temperature $(P<0.05)$, although in all treatments, the temperature was within the normal physiological range. The effects of protein, methionine and lysine level and interaction between protein and methionine and lysine and methionine on bouts of diarrhoea were different $(P<0.05)$. Also the effects of protein and lysine level and interaction between protein and lysine and protein and methionine on rectum temperature differed $(P<0.05)$. Totally, calves that received T3 had lower rectum temperatures and fewer bouts of diarrhoea. The results of the diets on health measurements, including bouts of diarrhoea, rectum temperature, serum IgG concentration and serum total protein, are presented in Table 4.

Serum IgG concentration and total protein were not different between treatments either at day 30 or at day 70 of the study. Also there was no significant main or interaction effects on these measures $(P>0.05)$.

Total serum protein is correlated with $\mathrm{IgG}$, and total protein above $5.2 \mathrm{~g} / \mathrm{dL}$ indicates good inactive immunity transfer in a healthy calf, but does not have any relation to calf growth (Batman, 2012). Total serum protein concentration is influenced by calf breed, age, dam parity, transition diet, dystocia, season and environmental temperature (Quigley et al., 1998).

Neither CP level nor main nor interaction effects had any effect on IgG concentration and total serum protein, indicating that dietary treatments did not influence the immunity of calves. However, bouts of diarrhoea were fewer and rectum temperature was lower in calves that received T3 and T7, showing that better AA balance can lead to a better health situation, because some studies reported immunity effects for AAs such as glutamine ( $\mathrm{Li}$ et al., 2007; Caroprese, 2012). Thus the addition of lysine and methionine may have enhanced AA balance and led to a positive effect on health parameters (Li et al., 2007).

Senevirathen et al. (2017) demonstrated that CP level did not influence scouring frequency, which is not in line with the present study, as there were differences in this parameter between the CP levels. In other research, more energy and protein uptake by calves resulted in an increase in faecal scours and more days in which they suffered from diarrhoea (Brown et al., 2005). Brscic et al. (2014) showed that calves that received more natural protein per day had fewer days on which they were treated for respiratory disease than those supplemented with urea. In the present study, calves that received T3 had fewer days on which they were treated for diarrhoea, which may be due to better amino acid balance, than on diets with higher CP level.

There were no differences in serum creatinine and urea between treatments at day 30 of the experiment $(P>0.05)$. However, dietary effects on urea differed at day $70(P<0.0001)$. There was an effect of protein on creatinine only at day 30 . Calves that received $18 \% \mathrm{CP}$ had lower serum urea. There was no effect of lysine and methionine on urea and creatinine. The results of serum creatinine and urea measurements are presented in Table 5.

The concentration of blood urea was lower in calves that received $18 \% \mathrm{CP}$ in starter, indicating that this group used dietary nitrogen more efficiently, which may be because of a better amino acid balance. This finding is in line with the study by Hill et al. (2008, who showed that a lower amount of methionine in milk replacer caused the greatest serum concentration of urea nitrogen, indicating inefficient use of dietary nitrogen. However, the creatinine concentrations of calves fed with experimental diets were not significantly different.

The level of lysine was not different in treatments with or without supplemented lysine, which is probably because of the higher corn in diets with no additional lysine. But the supplemental lysine was rumen protected, and if any differences were observed in calves' performance, it may be because of its absorption in intestine. 
Table 2 Starter intake, average daily gain, feed efficiency and body weight of dairy calves during 70 days fed with eight diets that differed in crude protein, lysine and methionine level

\begin{tabular}{|c|c|c|c|c|c|c|c|c|c|c|}
\hline \multirow{4}{*}{ Item } & \multicolumn{8}{|c|}{ Experimental diets } & \multirow{4}{*}{ SE } & \multirow{4}{*}{$P$ - value ${ }^{1}$} \\
\hline & \multicolumn{4}{|c|}{$18 \%$ crude protein } & \multicolumn{4}{|c|}{ CP $22 \%$ crude protein } & & \\
\hline & \multicolumn{2}{|c|}{ Basal lysine } & \multicolumn{2}{|c|}{$+20 \%$ lysine } & \multicolumn{2}{|c|}{ Basal lysine } & \multicolumn{2}{|c|}{$+20 \%$ lysine } & & \\
\hline & Basal Met & $+20 \%$ Met & Basal Met & $+20 \%$ Met & Basal Met & $+20 \%$ Met & Basal Met & $+20 \%$ Met & & \\
\hline Average daily milk DMI, kg/d & 0.575 & 0.575 & 0.575 & 0.575 & 0.575 & 0.575 & 0.575 & 0.575 & - & - \\
\hline \multicolumn{11}{|l|}{ Starter intake, $\mathrm{kg} / \mathrm{d}$} \\
\hline Pre-weaning & $0.399^{a b}$ & $0.360^{\mathrm{bc}}$ & $0.476^{\mathrm{ab}}$ & $0.436^{\mathrm{ab}}$ & $0.530^{\mathrm{a}}$ & $0.225^{c}$ & $0.458^{\mathrm{ab}}$ & $0.499^{a b}$ & 0.028 & 0.003 \\
\hline Post weaning & $1.630^{\mathrm{ab}}$ & $1.497^{b c}$ & $1.727^{\mathrm{ab}}$ & $1.485^{\mathrm{bc}}$ & $1.899^{a}$ & $1.358^{c}$ & $1.761^{\mathrm{ab}}$ & $1.571^{b c}$ & 0.095 & 0.004 \\
\hline Overall & $0.645^{\mathrm{ab}}$ & $0.587^{a b}$ & $0.726^{\mathrm{ab}}$ & $0.646^{\mathrm{ab}}$ & $0.804^{a}$ & $0.451^{\mathrm{c}}$ & $0.718^{a b}$ & $0.674^{\mathrm{ab}}$ & 0.055 & 0.001 \\
\hline \multicolumn{11}{|l|}{$A D G, \mathrm{~kg} / \mathrm{d}$} \\
\hline Pre-weaning & $0.577^{b c}$ & $0.582^{b c}$ & $0.638^{a}$ & $0.599^{a b}$ & $0.681^{a}$ & $0.494^{c}$ & $0.604^{a}$ & $0.632^{a}$ & 0.027 & 0.045 \\
\hline Post weaning & 0.612 & 0.692 & 0.722 & 0.678 & 0.784 & 0.520 & 0.808 & 0.766 & 0.085 & 0.284 \\
\hline Overall & $0.584^{b c}$ & $0.604^{b}$ & $0.66^{\mathrm{ab}}$ & $0.614^{\mathrm{ab}}$ & $0.701^{a}$ & $0.499^{c}$ & $0.645^{\mathrm{ab}}$ & $0.659^{a b}$ & 0.032 & 0.001 \\
\hline \multicolumn{11}{|l|}{ Gain-feed ratio 2} \\
\hline Pre-weaning & 0.620 & 0.650 & 0.633 & 0.612 & 0.650 & 0.639 & 0.622 & 0.644 & 0.022 & 0.895 \\
\hline Post weaning & 0.428 & 0.512 & 0.477 & 0.563 & 0.466 & 0.408 & 0.520 & 0.538 & 0.064 & 0.651 \\
\hline Overall & 0.564 & 0.611 & 0.587 & 0.590 & 0.596 & 0.577 & 0.585 & 0.614 & 0.017 & 0.514 \\
\hline \multicolumn{11}{|l|}{ Bodyweight, kg } \\
\hline Weaning, d 56 & $70.91^{b c}$ & $71.16^{\mathrm{bc}}$ & $74.34^{\mathrm{ab}}$ & $72.12^{\mathrm{ab}}$ & $76.71^{a}$ & $66.22^{c}$ & $72.39^{a b}$ & $73.98^{\mathrm{ab}}$ & 1.786 & 0.007 \\
\hline Final, d 70 & $79.48^{b c}$ & $80.86^{b}$ & $84.45^{\mathrm{ab}}$ & $81.63^{a b}$ & $87.69^{a}$ & $73.5^{c}$ & $83.71^{\mathrm{ab}}$ & $84.71^{a b}$ & 2.242 & 0.002 \\
\hline CP intake ${ }^{3}, \mathrm{~g} / \mathrm{d}$ & $118.35^{\mathrm{cde}}$ & $107.89^{\mathrm{de}}$ & $133.29^{\mathrm{bcd}}$ & $118.33^{\text {cde }}$ & $175.89^{a}$ & $98.68^{e}$ & $157.11^{\mathrm{ab}}$ & $147.36^{\mathrm{abc}}$ & 10.952 & $<0.001$ \\
\hline Lysine intake ${ }^{2}, \mathrm{~g} / \mathrm{d}$ & $5.900^{\mathrm{bc}}$ & $5.372^{\mathrm{cd}}$ & $6.640^{\mathrm{abc}}$ & $5.903^{b c}$ & $7.797^{a}$ & $4.376^{d}$ & $6.966^{\mathrm{ab}}$ & $6.536^{\mathrm{ab}}$ & 0.510 & $<0.001$ \\
\hline Methionine intake ${ }^{2}, \mathrm{~g} / \mathrm{d}$ & $1.652^{\mathrm{b}}$ & $1.551^{\mathrm{bc}}$ & $1.860^{\mathrm{ab}}$ & $1.705^{\mathrm{ab}}$ & $2.099^{a}$ & $1.246^{c}$ & $1.876^{\mathrm{ab}}$ & $1.854^{\mathrm{ab}}$ & 0.141 & 0.004 \\
\hline
\end{tabular}

${ }^{1}$ Significance of the 3-factor interaction of protein level, lysine and methionine; Met: methionine

2 Milk consumption included

${ }^{3}$ Only from starter

a,b Values within a row with a common superscript are not different at $P=0.05$ 
Table3 Skeletal growth parameters of dairy calves during 70 days fed with eight diets that differed in crude protein, lysine and methionine levels

\begin{tabular}{|c|c|c|c|c|c|c|c|c|c|c|}
\hline \multirow{4}{*}{ Item } & \multicolumn{8}{|c|}{ Experimental diets } & \multirow{4}{*}{ SE } & \multirow{4}{*}{ P-value ${ }^{1}$} \\
\hline & \multicolumn{4}{|c|}{$18 \%$ Crude protein } & \multicolumn{4}{|c|}{$22 \%$ Crude protein } & & \\
\hline & \multicolumn{2}{|c|}{ Basal Lysine } & \multicolumn{2}{|c|}{$+20 \%$ Lysine } & \multicolumn{2}{|c|}{ Basal Lysine } & \multicolumn{2}{|c|}{$+20 \%$ Lysine } & & \\
\hline & Basal Met & $+20 \% \mathrm{Met}$ & Basal Met & $+20 \% \mathrm{Met}$ & Basal Met & $+20 \%$ Met & Basal Met & $+20 \% \mathrm{Met}$ & & \\
\hline \multicolumn{11}{|c|}{ Body length, cm } \\
\hline Weaning & $54.38^{a}$ & $53.06^{\mathrm{abc}}$ & $54.04^{\mathrm{ab}}$ & $52.11^{b c}$ & $54.22^{\mathrm{ab}}$ & $51.79^{c}$ & $55.02^{a}$ & $54.99^{a}$ & 0.750 & 0.013 \\
\hline Final & $55.38^{a}$ & $54.06^{\mathrm{abc}}$ & $55.04^{\mathrm{ab}}$ & $53.11^{b c}$ & $55.22^{\mathrm{ab}}$ & $52.79^{c}$ & $56.02^{\mathrm{a}}$ & $55.99^{a}$ & 0.750 & 0.012 \\
\hline \multicolumn{11}{|c|}{ Body girth, $\mathrm{cm}$} \\
\hline Weaning & $110.92^{\mathrm{ab}}$ & $109.56^{\mathrm{bcd}}$ & $110.60^{\mathrm{abc}}$ & $108.96^{\mathrm{cd}}$ & $110.55^{\mathrm{abc}}$ & $108.44^{d}$ & $111.77^{a}$ & $111.02^{\mathrm{ab}}$ & 0.624 & 0.004 \\
\hline Final & $121.92^{\mathrm{ab}}$ & $120.08^{\mathrm{abc}}$ & $122.5^{\mathrm{ab}}$ & $119.81^{b c}$ & $122.59^{a b}$ & $117.51^{\mathrm{c}}$ & $122.81^{\mathrm{a}}$ & $122.53^{\mathrm{ab}}$ & 1.067 & 0.005 \\
\hline \multicolumn{11}{|c|}{ Wither height, $\mathrm{cm}$} \\
\hline Weaning & $81.88^{\text {cde }}$ & $83.19^{a b c}$ & $82.74^{\mathrm{bcd}}$ & $81.17^{e}$ & $82.99^{\mathrm{abcd}}$ & $81.83^{\mathrm{de}}$ & $83.77^{\mathrm{ab}}$ & $84.32^{a}$ & 0.476 & $<0.001$ \\
\hline Final & $89.64^{\mathrm{ab}}$ & $90.47^{a}$ & $90.31^{\mathrm{ab}}$ & $88.4^{\mathrm{bc}}$ & $90.81^{a}$ & $87.33^{c}$ & $90.15^{\mathrm{ab}}$ & $90.39^{a b}$ & 0.722 & 0.012 \\
\hline \multicolumn{11}{|c|}{ Hip height, $\mathrm{cm}$} \\
\hline Weaning & $90.48^{a b}$ & $90.74^{\mathrm{ab}}$ & $92.22^{\mathrm{a}}$ & $89.52^{b c}$ & $91.35^{\mathrm{ab}}$ & $87.88^{\mathrm{c}}$ & $90.64^{\mathrm{ab}}$ & $90.9^{a b}$ & 0.709 & 0.003 \\
\hline Final & $93.04^{\mathrm{ab}}$ & $92.91^{\mathrm{ab}}$ & $94.06^{\mathrm{a}}$ & $91.55^{\mathrm{bc}}$ & $93.38^{\mathrm{ab}}$ & $89.9^{c}$ & $92.65^{\mathrm{ab}}$ & $92.92^{\mathrm{ab}}$ & 0.698 & 0.003 \\
\hline \multicolumn{11}{|c|}{ Hip width, cm } \\
\hline Weaning & $19.81^{a}$ & $19.56^{\mathrm{ab}}$ & $20.23^{a}$ & $19.83^{a}$ & $19.61^{\mathrm{ab}}$ & $18.84^{b}$ & $19.67^{a b}$ & $20.41^{a}$ & 0.342 & 0.076 \\
\hline Final & $20.81^{a}$ & $20.56^{a b}$ & $21.23^{a}$ & $20.83^{a}$ & $20.61^{a b}$ & $19.84^{b}$ & $20.67^{a b}$ & $21.41^{\mathrm{a}}$ & 0.342 & 0.076 \\
\hline
\end{tabular}

${ }^{1}$ Significance of the 3-factor interaction of protein level, lysine and methionine, Met: methionine

a, b, c, d, e Values within a row with a common superscript are not different at $P=0.05$ 
Table 4 Health measurement of dairy calves during 70 days fed with eight diets that differed in crude protein, lysine and methionine levels

\begin{tabular}{|c|c|c|c|c|c|c|c|c|c|c|}
\hline \multirow{4}{*}{ Item } & \multicolumn{8}{|c|}{ Experimental diets } & \multirow{4}{*}{ SE } & \multirow{4}{*}{$P$-value ${ }^{1}$} \\
\hline & \multicolumn{4}{|c|}{$18 \%$ Crude protein } & \multicolumn{4}{|c|}{$22 \%$ crude protein } & & \\
\hline & \multicolumn{2}{|c|}{ Basal Lysine } & \multicolumn{2}{|c|}{$+20 \%$ Lysine } & \multicolumn{2}{|c|}{ Basal Lysine } & \multicolumn{2}{|c|}{$+20 \%$ Lysine } & & \\
\hline & Basal Met & $+20 \%$ Met & Basal Met & $+20 \%$ Met & Basal Met & $+20 \%$ Met & Basal Met & $+20 \%$ Met & & \\
\hline Days with diarrhoea & $5.003^{b}$ & $4.095^{c}$ & $3.496^{d}$ & $2.785^{\mathrm{e}}$ & $5.961^{\mathrm{a}}$ & $5.078^{\mathrm{b}}$ & $3.653^{d}$ & $4.925^{\mathrm{b}}$ & 0.148 & 0.001 \\
\hline Rectal temperature, ${ }^{\circ} \mathrm{C}$ & $38.94^{\mathrm{a}}$ & $38.69^{c}$ & $38.50^{e}$ & $38.34^{\dagger}$ & $38.60^{d}$ & $38.85^{b}$ & $38.65^{c d}$ & $38.84^{b}$ & 0.029 & 0.001 \\
\hline $\operatorname{lgG}, \mathrm{mg} / \mathrm{dL}$, day 30 & 10.509 & 10.101 & 13.338 & 17.219 & 10.706 & 10.621 & 10.923 & 11.027 & 2.394 & 0.368 \\
\hline $\mathrm{lgG}, \mathrm{mg} / \mathrm{dL}$, day 70 & 7.565 & 6.876 & 6.871 & 11.844 & 6.884 & 7.472 & 9.509 & 7.540 & 1.651 & 0.360 \\
\hline Total protein, g/dL, day 30 & 6.65 & 6.85 & 6.73 & 6.66 & 6.52 & 6.66 & 6.69 & 6.72 & 0.197 & 0.970 \\
\hline Total protein, g/dL, day 70 & 6.51 & 6.54 & 6.74 & 6.54 & 6.66 & 6.31 & 6.86 & 6.87 & 0.204 & 0.519 \\
\hline
\end{tabular}

IgG: immunoglobulin G, Met: methionine

1 Significance of the 3 -factor interaction of protein level, lysine and methionine, Met: methionine

$\mathrm{a}, \mathrm{b}, \mathrm{c}, \mathrm{d}, \mathrm{e}$ Values within a row with a common superscript are not different at $P=0.05$

Table 5 Serum parameters of dairy calves during 70 days fed with eight diets that differed in crude protein, lysine and methionine levels

\begin{tabular}{|c|c|c|c|c|c|c|c|c|c|c|}
\hline \multirow{4}{*}{ Item } & \multicolumn{8}{|c|}{ Experimental diets } & \multirow{4}{*}{ SE } & \multirow{4}{*}{$P$-value ${ }^{1}$} \\
\hline & \multicolumn{4}{|c|}{$18 \%$ Crude protein } & \multicolumn{4}{|c|}{$22 \%$ Crude protein } & & \\
\hline & \multicolumn{2}{|c|}{ Basal Lysine } & \multicolumn{2}{|c|}{$+20 \%$ Lysine } & \multicolumn{2}{|c|}{ Basal Lysine } & \multicolumn{2}{|c|}{$+20 \%$ Lysine } & & \\
\hline & Basal Met & $+20 \%$ Met & Basal Met & $+20 \%$ Met & Basal Met & $+20 \%$ Met & Basal Met & $+20 \%$ Met & & \\
\hline Urea, day 30 mg/dL & 18.75 & 22.25 & 21.29 & 22.58 & 22.4 & 22.72 & 25.45 & 23.92 & 2.157 & 0.397 \\
\hline Creatinine, day $30 \mathrm{mg} / \mathrm{dL}$ & 1.39 & 1.37 & 1.24 & 1.26 & 1.05 & 1.28 & 1.29 & 1.18 & 0.079 & 0.058 \\
\hline Urea, day 70 mg/dL & $21.18^{d}$ & $21.93^{\mathrm{cd}}$ & $23.63^{\mathrm{cd}}$ & $20.25^{d}$ & $30.41^{b c}$ & $34.5^{\mathrm{ab}}$ & $33.21^{\mathrm{b}}$ & $42.48^{\mathrm{a}}$ & 3.136 & $<0.001$ \\
\hline Creatinine, day $70 \mathrm{mg} / \mathrm{dL}$ & 1.19 & 1.2 & 1.18 & 1.1 & 1.15 & 1.03 & 1.18 & 1.23 & 0.065 & 0.426 \\
\hline
\end{tabular}

${ }^{1}$ Significance of the 3-factor interaction of protein level, lysine and methionine, Met: methionine

a, b, c, d Values within a row with a common superscript are not different at $P=0.05$ 


\section{Conclusion}

Feed efficiency was not different between experimental diets before and after weaning and during the experiment. But starter intake was higher when it was supplemented with lysine. When T3 was used, the final weight was similar to $22 \%$ CP with or without supplemental AAs. No clear trend was observed in skeletal growth between treatments. In spite of similar IgG and total blood protein concentrations, the addition of lysine and methionine decreased bouts of diarrhoea, and lower CP level led to a decrease in blood urea concentration and consequently to better utilization of nitrogen. Thus, a diet containing $18 \% \mathrm{CP}$ supplemented with lysine and methionine can be recommended as a starter ration for dairy calves.

\section{Acknowledgements}

The authors are grateful to the University of Tehran, Goldasht Nemooneh Plantation and Domesticated Co. and Arona company for grant and financial support and their help in executing this study.

\section{Authors' Contributions}

MN conducted the research and wrote the manuscript, based on MN's PhD thesis. KR and MG designed the experiment. All authors analysed and interpreted the results of the study. All authors approved the final version of the manuscript.

\section{Conflict of Interest Declaration}

The authors declare no conflict of interest.

\section{References}

Babu, L.K., Pandey, H.N. \& Sahoo, A., 2003. Effect of individual versus group rearing and feeding of different levels of milk and skim milk on nutrient utilization in crossbred calves. Asian- Austral. J. Anim. Sci. 16(10), 1455-1459. https://doi.org/10.5713/ajas.2003.1455

Bartlett, K.S., McKeith, F.K., VandeHaar, M.J., Dahl, G.E. \& Drackley, J.K., 2006. Growth and body composition of dairy calves fed milk replacers containing different amounts of protein at two feeding rates. J. Anim. Sci. 84, $1454-1467$. https://doi.10.2527/2006.8461454x

Bateman, H.G., Hill, T.M., Aldrich, J.M., Schlotterbeck, R.L. \& Firkins, J. L., 2012. Meta-analysis of the effect of initial serum protein concentration and empirical prediction model for growth of neonatal Holstein calves through eight weeks old. J. Dairy Sci. 95, 363-369. DOI: 10.3168/jds.2011-4594

Blome, R.M., Drackley, J.K., McKeith, F.K., Hutjens, M.F. \& McCoy, G.C., 2003. Growth, nutrient utilization, and body composition of dairy calves fed milk replacers containing different amounts of protein. J. Anim. Sci. 81, 1641-1655. https://doi.org/10.2527/2003.8161641x

Brown, E.G., VandeHaar, M.J., Daniels, K.M., Liesman, J.S., Chapin, L.T., Keisler, D.H. \& Weber Nielsen, M.S., 2005. Effect of increasing energy and protein intake on body growth and carcass composition of heifer calves. J. Dairy Sci. 88, 585-594. https://doi.org/10.3168/jds.S0022-0302(05)72722-3

Brscic, M., Prevedello, P., Stefani, A.L., Cozzi, G. \& Gottardo, F., 2014. Effects of the provision of solid feeds enriched with protein or nonprotein nitrogen on veal calf growth, welfare, and slaughter performance. J. Dairy Sci. 97, 1-9. https://doi.org/10.3168/jds.2013-7618

Caroprese, M., Albenzio, M., Santillo, R. \& Sevi, A., 2012. Immune response and milk production of dairy cows fed graded levels of rumen-protected glutamine. Research in Vet. Sci. 93, 202-209. https://doi.org/10.1016/j.rvsc.2011.07.015

Daneshvar, D., Khorvash, M., Ghasemi, E. \& Mahdavi, A.H., 2017. Combination effects of milk feeding methods and starter crude protein concentration: Evaluation on performance and health of Holstein male calves. Anim. Feed Sci. \& Tech. 223, 1-12. https://doi.org/10.1016/j.anifeedsci.2016.10.025

Guoyao, W., Fuller, W.B., Zhaolai, D., Defa, L., Junjun, W. \& Zhenlong, W., 2014. Amino acid nutrition in animals: Protein synthesis and beyond. Ann. Rev. Anim. Biosci. 2, 387-417. https://www.annualreviews.org/doi/abs/10.1146/annurevanimal-022513-114113

Hill, T.M., Aldrich, J.M., Schlotterbeck, R.L. \& Bateman II, H.G., 2006b. Effects of feeding rate and concentrations of protein and fat of milk replacers fed to neonatal calves. Prof. Anim. Scientist 22, 374-381. https://doi.org/10.15232/S10807446(15)31130-X

Hill, T.M., Aldrich, J.M., Schlotterbeck, R.L. \& Bateman II, H.G., 2007b. Amino acids, fatty acids, and fat sources for calf milk replacers. Prof. Anim. Scientist 23, 401-408. https://doi.org/10.15232/S1080-7446(15)30995-5

Hill, T.M., Bateman II, H.G., Aldrich, J.M. \& Schlotterbeck, R.L., 2007c. Effects of the feeding rate of high protein calf milk replacers. Prof. Anim. Scientist. 23, 649-655. https://doi.org/10.15232/S1080-7446(15)31036-6

Hill, T.M., Bateman II, H.G., Aldrich, J.M., Schlotterbeck, R.L.\& Tanan, K.G., 2008. Optimal concentrations of lysine, methionine, and threonine in milk replacers for calves less than five weeks of age. J. Dairy Sci. 91, $2433-2442$. https://doi.org/10.3168/jds.2007-0610

Jenkins, K.J. \& Emmons, D.B., 1983. Fortification of calf milk replacers with amino acids in free form or plastein-bound. Can. J. Anim. Sci. 63, 893-903. https://doi.org/10.4141/cjas83-104 
Kanjanapruthipong, J., 1998. Supplementation of milk replacers containing soy protein with threonine, methionine, and lysine in the diets of calves. J. Dairy Sci. 81, 2912-2915. https://doi.org/10.3168/jds.S0022-0302(98)75852-7

Kertz, A.F., Prewitt, L.R. \& Everett, Jr, J.P., 1979. An early weaning calf program: Summarization and review. J. Dairy Sci. 62, 1835-1843. https://doi.org/10.3168/jds.S0022-0302(79)83508-0

Khan, M.A., Lee, H.J., Lee, W.S., Kim, H.S., Kim, S.B., Ki, K.S., Park, S.J., Ha, J.K. \& Choi, Y.J., 2007. Starch source evaluation in calf starter: i. feed consumption, body weight gain, structural growth, and blood metabolites in Holstein calves. J. Dairy Sci. 90, 5259-5268. https://doi:10.3168/jds.2007-0338

Li, H.Q., Diao, Y., Zhang, N.F. \& Fan, Z.Y., 2008. Growth, nutrient utilization and amino acid digestibility of dairy calves fed milk replacers containing different amounts of protein in the preruminant period. Asian-Austral. J. Anim. Sci. 21 (8), 1151-1158. https://doi.org/10.5713/ajas.2008.70562

Li, P., Yin, Y.L., Li, D., Kim, S.W. \& Wu, G., 2007. Amino acids and immune function: A review. Br. J. Nut. 98, $237-252$. https://doi.org/10.1017/S000711450769936X

Lohakare, J.D., Pattanaik, A.K. \& Khan, S.A., 2006. Effect of dietary protein levels on the performance, nutrient balances, metabolic profile and thyroid hormones of crossbred calves. Asian-Austral. J. Anim. Sci. 19(11), 1588-1596. https://doi.org/10.5713/ajas.2006.1588

Manso, T., Mantecon, A.R., Giraldez, F.J., Lavın, P. \& Castro, T., 1998. Animal performance and chemical body composition of lambs fed diets with different protein supplements. Small Rumin. Res. 29,185-191. https://doi.org/10.1016/S09214488(97)00122-3

NRC 2001. Nutrient requirements of dairy cattle. 7th revised edition. National Academy Press, Washington, DC, USA. pp. 214-233

Quigley, J. \& Drewry, J., 1998. Symposium: Nutrient and immunity transfer from cow to calf pre- and post-calving. J. Dairy Sci. 81, 2779-2790. https://doi.org/10.3168/jds.S0022-0302(98)75836-9

Senevirathne, N.D., Anderson, J.L., Gibbons, W.R. \& Clapper, J.A., 2017. Growth performance of calves fed microbially enhanced soy protein in pelleted starter. J. Dairy Sci. 100, 1-14. https://doi.org/10.3168/jds.2016-11221

Stamey, J.A., Janovick, N.A., Kertz, A.F. \& Drackley, J.K., 2012. Influence of starter protein content on growth of dairy calves in an enhanced early nutrition program. J. Dairy Sci. 95, 3327-3336. https://pubmed.ncbi.nlm.nih.gov/22612966/

Tahmasbi, A.M., Heidari Jahan Abadi, S. \& Naserian, A.A., 2014. The effect of two liquid feeds and two sources of protein in starter on performance and blood metabolites in Holstein neonatal calves. J. Dairy Sci. 97, $363-371$. https://www.sciencedirect.com/science/article/pii/S0022030213007704

Wang, J., Diao, Q., Tu, Y., Zhang, N. \& Xu, X., 2012. The limiting sequence and proper ratio of lysine, methionine and threonine for calves fed milk replacers containing soy protein. Asian-Austral. J. Anim. Sci. 25(2), 224-233. doi: 10.5713/ajas.2011.11190

White, J.A., Hart, R.J. \& Fry, J.C., 1986. An evaluation of the Waters Pico-Tag system for the amino-acid analysis of food materials. J. Clinical Lab. Automation 8 (4), 170-177. https://dx.doi.org/10.1155\%2FS1463924686000330 